\title{
Level of CRP Maternal Serum during Puerperium of Severe Preeclampsia
}

Julian Dewantiningrum, Zaki Hetami

Faculty of Medicine Diponegoro University, Semarang, Indonesia

\section{Article Info}

History:

Received : 05 Apr 2018

Accepted : 02 July 2018

Available : 30 July 2018

\begin{abstract}
Background: Severe preeclampsia is still a major problem in the world, because of the increased of maternal mortality due to cardiovascular diseases (CVD). Detection of CRP (high C-reactive protein) using the high sensitivity method is a usefull prediction for CVD among non preeclamptic patients. This study aimed to investigate the total of CRP levels in maternal serum of severe preeclampsia and normotensive.

Objective: To determine the differences levels of CRP among severe preeclampsia and normal pregnancy patients using hs CRP method

Method: A descriptive cross sectional study was conducted to 26 severe preeclampsia $(53 \%)$ and 23 normal pregnancy $(46,9 \%)$ subjects / patients in puerperial period (2-6 weeks) . Exclusion criteria were puerperal infection, chronic hypertension, metabolic syndrome, caesarean section delivery. All subjects were examined the levels of CRP using hs CRP method. maternal serum.

Result: The mean levels of CRP in severe preeclampsia was $4.73+3.57$ while in normotensive $2.42+4.14(\mathrm{p}<0.05)$. Severe preeclampsia group hada risk of increase CRP maternal serum 2.5 times compared to the normotensive group.

Conclusion: Level of CRP in patients with preeclampsia post partum is higher than patients with normal pregnancies.
\end{abstract}

Keywords: High Sensitivity C-Reactive Protein; severe preeclampsia; puerperal period; normotensive; CRP

\section{INTRODUCTION}

Maternal deaths in the world are mostly caused by bleeding $(27 \%)$, infection $(11 \%)$, pre-eclampsia and eclampsia(14\%). 1 According to the data from Indonesian Demographic Health Survey (IDHS), maternal death were caused by 359 to 100,000 of live births and severe preeclampsia contributes of $24 \%$.Maternal mortality of severe preeclampsia in the puerperal period is likely to be greater because of cardiovascular, cerebrovascular, renal, and thromboembolism complications. ${ }^{2}$

Cardiologic department commonly used hsCRP method to detect CRP as aprediction biomarker of acute coronary syndrome (ACS).

\footnotetext{
* Corresponding author:

Julian Dewantiningrum

E-mail: lia.percy@gmail.com
}

ACS risk is about 2.8 times higher in severe preeclampsia compared with normotensive pregnancy. $\underline{-}$ These biomarkers can be detected early, so patients can be educated to lifestyle modification and cardiologists can do early prophylactic treatment of ACS. $\stackrel{4}{ }$ Recent research showed a link between severe preeclampsia and levels of maternal CRP serum using the hsCRP method. CRP will still increase during less than 2 weeks of postnatal period due to inflammatory process. This marker in severe preeclampsia remained high but still unclear whether CRP maternal serum level in the postnatal period of 2 to 6 weeks. One of advantage knowing CRP earlier at postnatal period, it will easier to educate patient for lifestyle modification, same as educate for contraception. So the purpose of this study was to determine the level of maternal serum CRP levels in puerperal period of severe preeclampsia compared 
with normotensive subjects / patients using the hs CRP method in the postnatal period at 2 to 6 weeks.

\section{MATERIALS AND METHODS}

The method of this study was descriptive research using cross sectional design. The inclusion criteria were subjects in puerperal period with a history of severe preeclampsia and normotensive. Exclusion criteria were puerperal infection, metabolic syndrome andcaesarean section delivery. Puerperal period was between $2-6$ weeks after delivery. Severe preeclampsia were diagnosed using criteria at least one of the following symptoms blood pressure $\geq$ $160 / 110 \mathrm{mmHg}$, proteinuria $\geq 5 \mathrm{~g} / 24$ hours or $\geq+2$ dipstick and one organ involvement: thrombocytopenia $\quad(<100.000 / \mathrm{ul}), \quad$ hemolysis microangiopati, increasing SGOT and SGPT, the persistence of headache, eyesight scotoma, fetus: fetal growth retardation, oligohydramnios, pulmonary edema or congestive heart failure, oliguria $(\leq 500$ $\mathrm{ml} / 24$ hours) and serum creatinine $\geq 1,2 \mathrm{mg} / \mathrm{dL}$.
Maternal serum were taken from venous blood samples about $5 \mathrm{cc}$ fromthe median cubital vein. Those serum were taken from severe preeclampsia when blood pressure $\leq 140 / 90$. CRP serum level were measured using hsCRP method with LTIA (Latex Turbidimetric Immunoassay). Other demographic and clinical variables were included such as age, gravidity, parity, abortion, gestational age when delivery, body mass index (BMI), birthweight, education, occupation and methods of vaginal deliveryto know the differences between two groups.

\section{RESULTS}

Table 1 showed that characteristics of subjects were almost homogen. The difference among two groups was method of vaginal delivery, because mostly vacuum extraction has done for accelerate delivery of severe preeclampsia. Severe preeclampsia delivered with vacuum extraction at $68 \%$ of women and the majority of normotensive woman delivered baby spontaneously $(62,5 \%)$.

Table 1. Characteristics of subjects

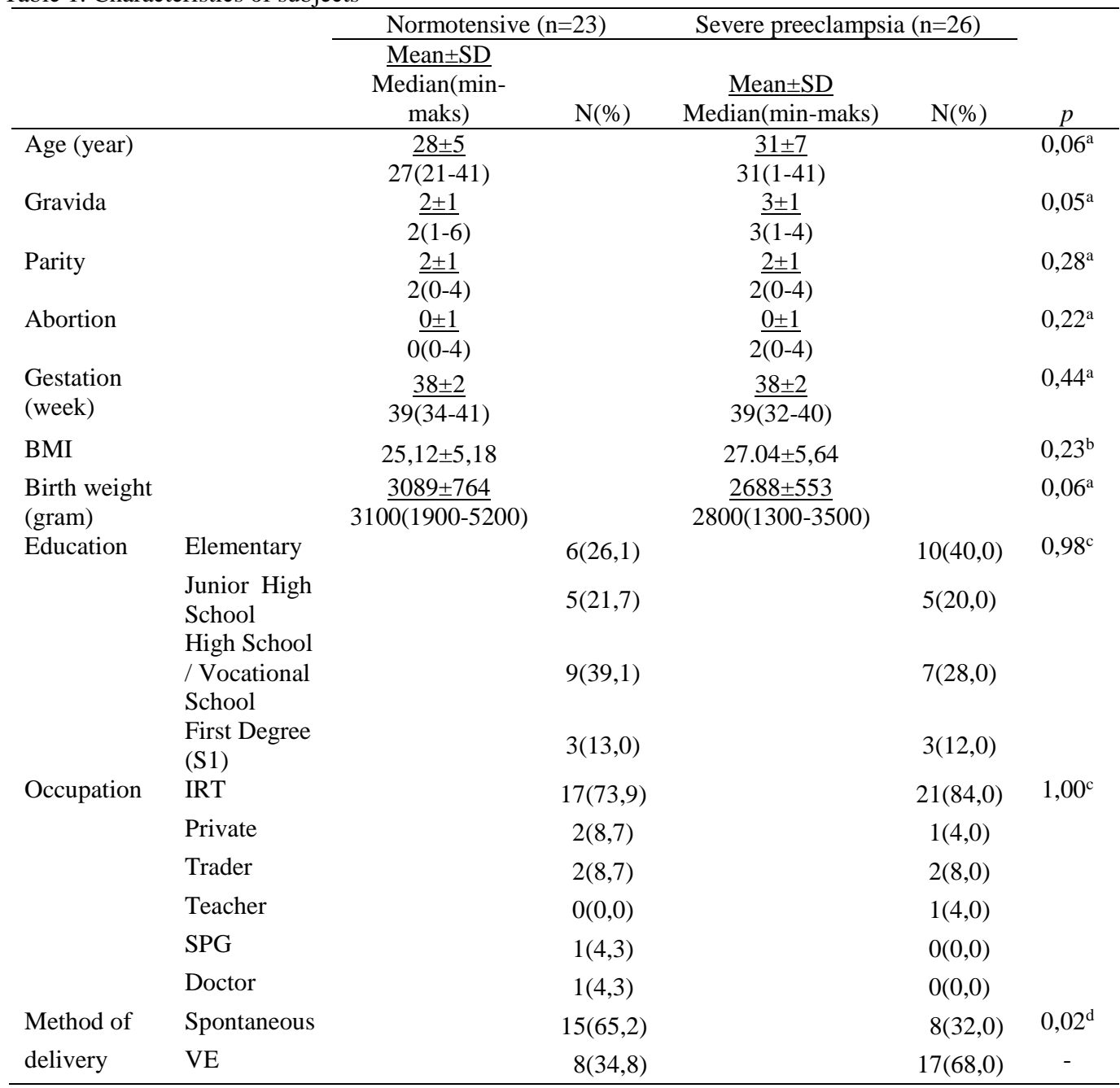
a. Mann Whitney Test
b. Independent TTest
c. Kolmogorov Smirnov Test
d. $X^{2}$ Test 
Table 2. The maternal serum of hsCRP of severe preeclampsia and normotensive.

\begin{tabular}{cccc}
\hline Group & $\begin{array}{c}\text { Normotensive } \\
(\mathrm{n}=23)\end{array}$ & $\begin{array}{c}\text { Severe } \\
\text { preeclampsia } \\
(\mathrm{n}=26)\end{array}$ & $\mathrm{p}$ \\
\hline $\begin{array}{c}\text { hsCRP }(\mathrm{mg} / \mathrm{L}) \\
\text { mean }+ \text { SD } \\
\text { Relative risk(RR) }\end{array}$ & $2,42 \pm 4,14$ & $4,73 \pm 3,57$ & $0,0001^{\mathrm{a}}$ \\
\hline
\end{tabular}

Table 2 showed the average levels of hsCRP in normotensive women $(2.42 \mathrm{mg} / \mathrm{L})$ was lower than preeclamptic group $(4.73 \mathrm{mg} / \mathrm{L}), \mathrm{p}$ value $=0.0001$ $(<0.05)$. Severe preeclampsia increased the risk of hsCRP level was 2.5 times compared with normotensive.

\section{DISCUSSION}

In general, CRP shows the degree of inflammatory activityduring early 2 weeks of postnatal period. $\stackrel{7}{ }$ The high inflammatory activity were occurred in early puerperal period $(6-12$ firsthour). After that, the inflammatory activity were decrease until 2 weeks and steady state until the end of puerperal period. ${ }^{8}$ So, this study measured hsCRP at $2-6$ weeks of puerperal period. If hsCRP > 10 $\mathrm{mg} / \mathrm{L}$ reflect high inflammatory activity or acute infection. ${ }^{9}$ The level of hsCRP in this study were $<10$ $\mathrm{mg} / \mathrm{L}$. It means that the inflammatory activity were decreased.

Many studies concluded that severe preeclampsia increased risk of cardiovascular complication related with chronic hypertension and metabolic syndrome such as dislipidemiaand insulin resistant. ${ }^{10}$ This study focused on woman with severe preeclampsia without metabolic syndrome comorbodities. BMI were similar between two groups.CRP in cardiology department were measured to predict risk of ACS in healthy people, before appear of significant clinical sign.CRP $\geq 3-10 \mathrm{mg} / \mathrm{L}$ was categorized as high risk of cardiovascular complication. ${ }^{7}$

In this study, patients with severe preeclampsia had higher maternal CRP serum level than normotensive patients in puerperal period. This result similar with other former studies. ${ }^{4,6}$, We conclude that CRP maternal serum detected by hsCRP method at puerperal period can be used as a masker for prediction of ACS. If patients can be aware earlier, it will easier to educate them with life style modification.

\section{REFERENCES}

1. World Health Organization. Maternal mortality. Avalaible from: http://www.who.int/mediacentre/factsheets/fs348/e n/. Last accesessed: April 10, 2014. 2014.

2. Kementerian Kesehatan Republik Indonesia. Peraturan Menteri Kesehatan Republik Indonesia Nomor 2565 Tahun 2011. (The Ministry of Health Republic Indonesia. Regulation of the Health Minister of the Republic Indonesia No. 2565 Year 2011).

3. Wikstrom A, Haglund B, Olovsson M, Lindeberg S. The Risk of Maternal Ischaemic Heart Disease after Hypertensive Disease. BJOG. 2005(112):1486-91.

4. Setiawan I, Wardhani V, Sargowo D. Akurasi Fibrinogen dan Hs-CRP sebagai Biomarker pada Sindroma Koroner Akut. J Kedokteran Brawijaya. 2011;26(4):233-9.

5. Fatemeh M, Fatemeh R, Hossian AK. Association of Maternal Serum C- Reactive Protein Levels with Severity of Preeclampsia. Acta Medica Iranica 2009;47(4):293-6.

6. Hwang HS, Kwon JY, Kim MA, Park YW, Kim YH. Maternal serum highly sensitive C-reactive protein in normal pregnancy and pre-eclampsia. Int J Gynaecol Obstet. 2007;98(2):105-9.

7. Tavana ZM, Zholghadri JD. The Relationship between Maternal serum highly sensitive CReactive Protein, Leptin and Hypertensive disorder of Pregnancy. The Internet Journal of Endocrine. 2010;6(2).

8. Romano M, Cacciatore A, Giordano R, La Rosa B. Postpartum period: three distinct but continuous phases. J Prenat Med. 2010;4(2):22-5.

9. Hubel CA, Powers RW, Snaedal S, Gammill HS, Ness RB, Roberts JM, et al. C-reactive protein is elevated 30 years after eclamptic pregnancy. Hypertension. 2008;51(6):1499-505.

10. Vallejo Vaz AJ, Guisado ML, Garcia-Junco PS, Andreu EP, Morillo SG, Ortiz JV. Differences in the prevalence of metabolic syndrome and levels of C-reactive protein after puerperium in women with hypertensive disorders during pregnancy. Hypertens Res. 2010;33(10):1012-7.

11. Ann-Charlotte I. Inflammatory mechanisms in preeclampsia. Pregnancy Hypertension: An International Journal of Women's Cardiovascular Health. 2013;3(2):58. 